\title{
[pre-proofing version]
}

The third army: wandering soldiers and the negotiation of parliamentary authority, 1642-51

David J. Appleby

Harassed officials struggling to cope with the burdens of civil war might well have empathised with the old German proverb which states that 'war leaves a country with three armies: one of cripples, one of mourners, and one of thieves.' ${ }^{1}$ The wars in Charles I's three kingdoms devoured some 540,000 human beings and spat out many more half-chewed. ${ }^{2}$ Thousands of civilian refugees, maimed soldiers and war widows trod the roads of England and Wales. Churchwardens routinely provided financial assistance to facilitate their onward journey. At the same time, parish officials had to deal with a more menacing figure: the socalled 'wandering soldier'. These individuals could be disbanded veterans or escaped prisoners-of-war, but were very often deserters. Wandering soldiers were unsupervised, generally able-bodied, and very often armed. Whether such men posed a genuine threat to local communities will be considered below, but it is clear that there were a great many of them, and that they presented the authorities with serious problems.

C. H. Firth's ground-breaking Cromwell's Army (1902) encouraged historians to consider the social world of early modern soldiers, and their relations with civilian communities. ${ }^{3}$ Remarkably, it was not until 1991 that the issues of demobilisation and desertion were considered in any depth, with Ronan Bennett's essay on policing in civil-war Yorkshire, and the invidious effects of unsupervised soldiery. ${ }^{4}$ In 1992 Ian Gentles dispelled the myth of the New Model's efficiency by emphasising the strategic implications of its high desertion rates. More recently, Barbara Donagan has offered a series of valuable insights into the nature of desertion. ${ }^{5}$ It is still the case, however, that far more is known about wandering soldiers of other periods. Philip Thomas, Gervase Phillips and Linda Salamon have explored the world of Elizabethan deserters and veterans, whilst John Childs has highlighted links between demobilisation and crime in the later seventeenth century. Desertion in the eighteenth century has been covered by scholars such as Neal Garnham and Thomas Agostini. ${ }^{6}$

A student of the civil wars will rarely find such detailed sources as those utilised by Garnham and Agostini, and the difficulties of seeking to liberate marginalised groups from the condescension of posterity are well known. However, the fact that we now know that early modern vagrants did not wander aimlessly, and that crowds were not mindless mobs shows what can be achieved if individuals, events and mentalities are placed within their proper historical context, and subjected to structured analysis. ${ }^{7}$ Peter Burke and John Walter, influenced by social anthropologists such as Clifford Geertz and James C. Scott, have demonstrated the efficacy of constructing narratives that operate 'on several levels and within various time spans'. ${ }^{8}$ The intention here is to demonstrate that the issues surrounding wandering soldiers were complex and mutable, and should be placed within wider historiographical debates concerning the negotiation of authority in early modern England.

Desertion was so endemic to early modern armies that Gentles has described recruitment as akin to ladling water into a leaky bucket. ${ }^{9}$ Mounted troops were less likely to desert than foot soldiers, for the simple reason that most horsemen were volunteers. Cavalry troopers tended to come from the respectable middling sort, and, being more literate than the average soldier, were more cognisant of the cause they served. On the rare occasions when cavalry or dragoons had to be conscripted, the authorities tried to select well-affected individuals of good character; after all it was unwise to conscript an unreliable man only to 
provide him with a horse on which to escape. ${ }^{10}$ Naturally, there were occasions when cavalry commanders discovered knaves in their unit. Two such men were admitted into the troop of Oliver Cromwell junior but, finding less opportunity for plundering than they anticipated, they deserted, taking their horses and weapons with them. Cromwell described them as 'dishonorers of God's cause, and high displeasers of my father, my selfe and the whole regiment'. ${ }^{11}$ These tended to be isolated incidents, however, unlike the infantry, who deserted in droves. Most foot soldiers were conscripts, and even volunteers were rarely as eager as propagandists pretended. Volunteers for Parliament's field army in 1642 were privately described as 'runaway cowards', one official declaring that he had 'never seen such indisposition in men to the service in my life. ${ }^{12}$ It is telling that the first assignment given to dragoons raised in Essex in 1643 was to herd hundreds of their impressed fellow countrymen north to the Eastern Association army. ${ }^{13}$

Parliament's shift in emphasis from a regionalised war effort to a national one over the winter of 1644-45 exacerbated the problem. As money was diverted from regional armies to finance the New Model Army, cash-strapped local commanders struggled to retain their men. ${ }^{14}$ The foot regiments of the New Model itself, although initially well-funded, were heavily dependent on conscription and even more prone to mass desertion. Thousands of conscripts did not even reach the front. Colonel John Venn reported to Parliament in April 1646 that the negligence of the Lincolnshire county committee had resulted in the escape of almost half of their latest crop of conscripts. Several hundred men had scattered before it had been possible to organise their conveyance. ${ }^{15}$ By this time it was considered advisable to provide at least one guard for every two impressed men. ${ }^{16}$ The royalist high command was similarly plagued by 'enlistment desertion': in April 1644 the earl of Forth sent two officers to Abingdon to collect 834 Berkshire conscripts, only to learn that 713 had already disappeared. Fifty-one more would abscond over the next two days. ${ }^{17}$

Venn suggested that the Lincolnshire incident was indicative of a deeper problem, declaring that:

most [counties] press the scum of all their inhabitants, the king's soldiers [i.e. prisoners-of-war], men taken out of prison, tinkers, pedlars and vagrants that have no dwelling, and such of whom no account can be given. It is no marvel if such run away. ${ }^{18}$

Venn's jaundiced analysis is at odds with desertion patterns in other periods. Most enlistment deserters from Count Mansfeld's expedition in 1624 had been artisans and husbandmen rather than vagrants, many indignant at being forced to leave their families on parish charity. ${ }^{19}$ Garnham and Agostini have observed a similar demographic among eighteenthcentury deserters. ${ }^{20}$ Venn's comments might even be questioned with respect to enlistment desertion in his own time; by 1646, having drained their respective catchment areas of marginalised males, both sides had begun to conscript breadwinners and householders. If these family men could give their guards the slip whilst still reasonably close to home, they had a reasonable chance of melting back into their native communities. County justices had proved remarkably sympathetic to such men in 1624, allowing them to return to their civilian occupations 'as soon as it could be done discreetly. ${ }^{21}$ Magistrates were even more circumspect during the civil wars, as leniency could easily be interpreted as disaffection, but many empathised with local complaints that conscription was causing depopulation and economic depression. ${ }^{22}$

Conductors (officers commanding conscript columns) knew that stopping to search for absconders only gave the other conscripts an opportunity to escape. They therefore hurried to deliver their remaining charges as quickly as possible. Months might elapse before 
the new recruits saw combat. This, and the fact that few could fully appreciate the horrors that awaited them, may explain why fear was low on the list of reasons to desert. Indeed, one contemporary argued that English soldiers in Ireland were more likely to desert if not engaged in fighting. ${ }^{23}$ Major-General Richard Browne did not list fear as a factor in January 1645 when attempting to explain to his superiors why his army had become so depleted. Instead he pleaded that the soldiers 'for want of pay, desert us daily, their duty is hard, their quarters very strait, victuals very scant, and no money sent to us. ${ }^{24}$ This reflects Gervase Markham's description of a soldier's life as one of 'sicknesse, mortality, slaughter, ill diet and lodging, hunger, cold and surfeits'. ${ }^{25}$ There were regular complaints that men were inadequately clothed. In the winter of 1643 an Eastern Association officer observed that 'the winter is already come, and our lying in the field hath lost us more men than have been taken away either by the sword or bullet. ${ }^{26}$ Such privations were exacerbated by boredom and brutal discipline, leaving little reason to wonder why men continued to desert long after they had joined their regiments.

Early modern military regulations invariably prescribed the death penalty for any soldier who strayed more than one mile from his army without licence. ${ }^{27}$ In actuality officers tended to exercise discretion when dealing with men who fled from the fight, and they were tacitly supported by generals who appreciated that they could do little more than execute a token handful of reprobates. Those who turned tail in the heat of battle risked being beaten or shot if caught in the act, but if they returned within a few hours there was a good chance that nothing more would be said. Commanders frequently allowed enemy troops to escape rather than risk their own men's lives trying to apprehend them. Captain Edward Kightley confided to his cousin that when he had encountered a large body of royalist deserters fleeing the battlefield at Edgehill in October 1642 he had 'let them passe, disarming them, and giving the spoile to my Troopers'. ${ }^{28}$ Although there were several occasions on which hundreds of captives changed sides after their army had been defeated, many officers chose not to recruit enemy deserters, and generally turned them loose rather than waste resources keeping them prisoner. When a Cavalier commander wrote to Thomas Bulstrode, parliamentarian governor of Aylesbury to protest that he had let royalist deserters go free, Bulstrode replied testily that 'this garrison is not suffered to be a receptacle for your fugitives.' 29

Stragglers fell into a slightly more serious category than battlefield runaways. These were men who went absent without leave whilst the army was on the move, but who might return after a few days. It was common practice to redistribute stragglers' pay and food around the rest of the unit, in the expectation that they would eventually return. Edward Kightley was typical in this respect:

I stop their pay, some of them for two dayes, some three dayes, and some four dayes, which time they were gone from me, and give their pay to the rest of the souldiers... ${ }^{30}$

This had the effect of punishing the delinquent whilst at the same time rewarding the rest for their fidelity. More serious punishments awaited turncoats and permanent deserters providing they could be caught. Early modern armies had a rudimentary policing system headed by a provost-marshal-general, but if deserters managed to put a few miles between themselves and their army they were unlikely to be pursued. Regimental provost-marshals ranked below lieutenants and quartermasters, despite having more duties. Naturally they were responsible for subduing and detaining offenders, but were also expected to patrol the camp, supervise the disposal of garbage and human excrement, collect and distribute captured booty, keep camp followers in order, monitor victuallers' goods and prices, and assist regimental quartermasters and wagon-masters with billeting and transportation. Seventeenth- 
century military theorists presumed that regimental provosts would be watchful for stragglers, but said nothing about pursuing deserters once they had escaped. ${ }^{31}$ Some commanders were more energetic than others: Lord John Byron diverted men from frontline duties in order to hunt down deserters, whilst the earl of Manchester detailed officers to retrieve men who absented themselves from his Eastern Association army. ${ }^{32}$ For the most part, however, the manuals reinforce the impression given by contemporary legislation; that it was the civilian authorities' responsibility to detect, detain, and return deserters to the military for punishment. Before considering how local officials coped with this burden it is necessary to appreciate the size and nature of the problem.

It is difficult to quantify the effect wandering soldiers had on civilian communities, but as there were significant numbers involved they must have had a significant impact. Part of the solution may lie in aligning entries in parish and county records with military events. There are, for example, well-documented instances of peaceful demobilisation: thousands of royalist troops were released into the community after the general capitulation of 1646. Royalist garrisons negotiated honourable terms and marched out in good order, but, having nowhere to go, they dispersed almost immediately. The soldiers of the Lichfield garrison were instructed to go home or stay with friends, on condition that they lived peaceably thereafter. ${ }^{33}$ Thousands of parliamentarians were discharged in 1647,1651 and 1654. Although these troops were released in an orderly manner, many retained their weapons, and several appear to have caused as much trouble as deserters.

Desertion was disorderly by definition, particularly when it involved large numbers. Gentles calculates that fully 4,000 soldiers of the New Model deserted following Parliament's victory at Naseby on 14 June $1645 .{ }^{34}$ Communities in the south Midlands and East Anglia did not simply have to contend with these men, however. According to the True Informer, 4,508 captured royalist soldiers were herded into Northampton the day after the battle. ${ }^{35}$ A number subsequently agreed to serve in Parliament's forces in Ireland. The remainder were to be set free, provided they could convince their captors that they would never again take arms against Parliament. Those unable or unwilling to do this were to be transported to Barbados. ${ }^{36}$ Around 1,500 prisoners were missing by the time the convoy marched through London on 21 June. Those who had accepted Parliament's terms may already have been detached, but there are indications that many prisoners had escaped during the march, in an incident near Barnet. ${ }^{37}$ By any calculation therefore, thousands of unsupervised able-bodied ex-soldiers were circulating around southern and eastern parishes from June 1645 onwards - a sizeable addition to those who had deserted royalist, parliamentarian and Scottish armies over the preceding years.

Many of these wandering soldiers were harmless, and simply intended to return home. As has already been noted, both sides quickly became so desperate for manpower that they were forced to pluck men from the heart of the community, as well as vagrants and ne'er-dowells. When respectable men deserted they often sought to legitimise their behaviour by emphasising the need to contribute to the wellbeing of their local community, such as helping with the harvest. Essex volunteers had deserted en masse in 1642 when they learned that their officers were to be replaced by strangers, and their companies assimilated into Parliament's main field army. Having enlisted on the assumption that they would only be expected to defend their own county, the men had no scruples about quitting Parliament's cause and heading home. ${ }^{38}$ The pull of localism was also evident in concerns that the enforced absence of breadwinners would cause financial difficulties for their families. Local leaders took steps to alleviate individual cases of hardship, but these were not sufficient to prevent further desertion. ${ }^{39}$ A soldier's plea to Sussex justices in 1645 that he had gone home to care for his aged mother had been heard before by magistrates elsewhere. ${ }^{40}$ Families were forced to beg for charity when men had seized the opportunity to desert their wife and children as well as 
the army. ${ }^{41}$ The desire to keep families off parish poor relief provided a powerful incentive for justices to respond slowly to pressure from higher authority to track down 'respectable' deserters.

The vast majority of pressed men came from the margins of society, however. In the Suffolk parish of Cratfield, for example, only two out of thirteen men taken for soldiers were ratepayers. ${ }^{42}$ Throughout the conflict petty constables invariably sought to meet their quotas by following Sir Robert Cotton's dictum that 'men of lesse livelihood were the best spared'. ${ }^{43}$ This encouraged civilians to assume that armies consisted principally of itinerant lowlife and the scum of the parish. As a result, even honest men returning home from the wars could find themselves shunned by their erstwhile friends and neighbours. ${ }^{44}$ Communities were snobbish about soldiers and at the same time intensely scared of them. 'The rugged Souldier that from War returns', Thomas Otway later wrote, 'still with heat of former Action burns' ${ }^{45}$ Lurid popular literature and increasing numbers of horrifically maimed veterans passing through their parishes left civilians with a vivid impression of the savagery of war. ${ }^{46}$ Sergeant Henry Foster wrote of his first experience of action that 'it were somewhat dreadful when men's bowels and brains flew in our faces', but he also noted how quickly he and others became desensitised to the horrors of the battlefield. ${ }^{47}$ Modern studies have found that some combatants come to derive intense gratification from killing - psychopathic behaviour which can be linked with other wartime activities such as rape and vandalism, and which is very often an attempt to compensate for feelings of powerlessness and inadequacy. ${ }^{48}$ There is mounting evidence that many others displayed signs of post-traumatic stress disorder. Entries in Quarter Sessions order books and other documents suggest that county officials were generally sympathetic to mentally-disturbed veterans and their families, even in cases where the individual posed a danger to themselves or others. ${ }^{49}$ However, it was one thing for a justice to deal with unpredictable veterans in the safe environment of the Quarter Sessions; it was quite another to be a parish official patrolling a lonely road, with orders to challenge passing strangers. Constables and churchwardens who confronted wandering soldiers were well aware that they were taking a serious risk. Magistrates' reports in earlier decades (particularly those in the vicinity of traditional embarkation centres such as Chester, Harwich and Portsmouth) had repeatedly linked unsupervised soldiers with robbery, rape and homicide. ${ }^{50}$ Historians have been too eager to dismiss these allegations as mere rhetoric, for, as Ronan Bennett has shown, wandering soldiers were guilty of very serious crimes in civilwar Yorkshire, including several murders. Among the victims was a petty constable, stabbed to death by a gang of soldiers whilst attempting to detain one of their comrades. ${ }^{51}$

As has been suggested earlier, marginalised males may actually have found army life less miserable than their previous existence - at least until disease, starvation and slaughter became too much to bear, or when the acquisition of plunder (as at Naseby) gave them something to live for. When men such as these deserted they became wandering soldiers in the truest sense of the term. 'Home' often had little to offer the most destitute of the resident poor, and it had even less meaning for those who had been vagabonds in civilian life.

Thousands of vagrants had trodden the highways and byways of England before the civil wars, and popular literature had long portrayed them as a catalyst for criminality. In contrast to the lively historiographical debate as to whether the caricatures created by Elizabethan 'rogue' literature induced a moral panic in early modern society, there has been little written on vagrancy between 1639 and 1660. ${ }^{52}$ This silence is remarkable, because far from reducing the numbers of vagrants the civil wars exacerbated the problem. Anthony Fletcher has noted that vagrancy 'reached alarming dimensions' during the mid-1640s, and it was not simply a question of numbers: many vagrants were now armed, trained and dangerous. ${ }^{53}$ John Awdelay's literary image of the 'ruffler' - the ex-soldier whose 'chiefest trade is to rob poor wayfaring men and market women' - had already linked veterans with vagrancy in the public 
mind, and the civil wars served to reinforce the perception. ${ }^{54}$ A report on the London hospitals in 1644 noted that whereas soldiers wounded in Parliament's service were being cared for in the great institutions of St Thomas's and St Bartholomew's, hundreds of wounded royalists, 'wandering soldiers, and other vagrant people' had been sent to the infirmary at Bridewell - already notorious as a house of correction. ${ }^{55}$ Honourably discharged soldiers were anxious to avoid being mistaken for vagrants: demobilised veterans presented a petition to Parliament in June 1647 pleading for their arrears to be paid before they obeyed a proclamation to leave London, in order that they should not 'perish like vagabonds' ${ }^{56}$

Looking back on the civil wars, James Howell declared that war was a seminary for thieves. ${ }^{57}$ This resonated with the sentiments in Thomas More's Utopia, which had been reprinted in 1639: 'Theeves be not the most false and faint-hearted Souldiers, nor souldiers bee not the cowardliest theeves, so well these two Crafts agree together.' ${ }^{58}$ Wandering soldiers were increasingly implicated in localised crime waves from 1645 onwards. Buckinghamshire was plagued by a gang of 'wood robbers' who had no loyalty to either side, and plundered indiscriminately. Some gang members who were caught claimed to be royalists, 'but the King will not own them'. ${ }^{59}$ The parliamentary committee for Dorset reported widespread criminal activity in their area by January 1646, noting that the gangs were mounted and armed, and causing fear and terror throughout the shire. ${ }^{60}$ Wiltshire experienced equally serious lawlessness, which justices there blamed squarely on wandering soldiers. In July 1646 they attempted to restore law and order by ordering towns and villages under their jurisdiction to arrange regular patrols of local roads, bridges and crossroads. Watchmen and tithingmen were to 'apprehend all wandering soldiers and mariners, rogues, vagabonds and suspicious persons that they shall meet with who cannot give good account of their travel. ${ }^{61}$ Heavy penalties were prescribed for communities or officials who neglected to do their duty. Despite an attempted crackdown in the areas under Parliament's control, at least one criminal gang was still causing trouble in Sussex in $1648 .{ }^{62}$

Criminal behaviour continued even when wandering soldiers began to set down roots. In November 1651 the Corporation of Rye described the economic dislocation which had arisen following an influx of disbanded soldiers, and pleaded for outside help to subdue and expel those who had no ties to the locality. Rye's burghers declared themselves powerless to deal with men who daily committed misdemeanours and indulged in 'evil behaviour', and who were 'imboldened to despise and contemne all Government and ministers'. ${ }^{63}$ They were not the only authority figures who found themselves unable to cope: order frequently broke down in military camps as well. In June 1645, parliamentarian commanders in Lancashire had found, like so many captains before them, that they had reason to fear their men more than the enemy. They too pleaded for help to placate unpaid and mutinous soldiers, who had 'beaten, struck, wounded, and imprisoned some of us', and were threatening to desert. ${ }^{64}$

Given their superiors' impotence in the face of such malevolence, it was understandable that constables and churchwardens rarely attempted to detain unsupervised soldiers passing through their parishes, despite instructions and threats from above. Soldiers usually deserted their armies in small groups, but sometimes as many as forty or fifty men could be led away by renegade sergeants. ${ }^{65}$ Of course, even the seven men who followed Corporal Atkins out of Browne's encampment at Abingdon in January 1645 could intimidate a civilian community. ${ }^{66}$ An incident involving West Ham churchwardens, who in February 1648 opted to pay a group of unruly soldiers 'to keep the quiet' rather than attempt any arrests, shows that civilians would do almost anything to avoid trouble. ${ }^{67}$ It was not always the wandering soldier who initiated the violence, however: one deserter apprehended following a tense armed standoff between ex-soldiers and locals in a Sussex alehouse in 1648 alleged that he had 
joined the gang primarily for reasons of personal safety. ${ }^{68}$ By the mid-1640s, soldiers on both sides had become adept at extorting food, horses and money from local communities, and many went well beyond their official remit. ${ }^{69}$ Such activities fuelled widespread antipathy towards the military, and motivated some civilians to assault wandering soldiers travelling alone.

In view of the numbers of military fugitives who passed through civilian localities in the 1640s and 50s, it is remarkable how few can be positively identified as wandering soldiers in parish accounts. Whilst it is important not to stray beyond the evidence, it is useful to consider how the fugitives presented themselves, and how churchwardens and constables in turn sought to reduce the risk of a potentially lethal encounter at the same time as they attempted to avoid being punished for dereliction of duty.

The first question to consider is whether parish officials could recognise a soldier when they saw one. Agostini has noted that eighteenth-century deserters regularly adopted disguises or invented stories to hide their identity. ${ }^{70}$ Seventeenth-century veterans were held to have discernible features which made such subterfuge difficult. In the New Model, as with many regiments in the armies that preceded it, soldiers tended to be issued with red coats, so much so that the wandering soldier in his ragged red coat became a stock image in ballads and plays. ${ }^{71}$ Observers also sometimes referred to soldiers' weather-beaten faces, as these tended to be more scarred, battered and tanned than civilians. Civilians engaged in outdoor occupations had a hard life, but they could sleep beside their hearths in extreme weather whereas soldiers were often bereft of any shelter. It was not until Cromwell's expedition into Scotland in 1650 that common soldiers were issued with tents. As a character in Edward Howard's play The Man of Newmarket says: 'I know you have been a Souldier, and deserve a handsome recompense, though men of your Complexion are not always fortunate to finde it. $^{72}$

Strangers in an unfamiliar locality invariably gave themselves away when they opened their mouths. Barbara Donagan's suggestion that 'deserters, even those far from home, could hope to fade into the general population' perhaps underestimates just how diverse English accents and dialects were during the early modern period. ${ }^{73}$ As the war became less regional in character armies campaigned further afield, and deserters were forced to travel ever greater distances to reach familiar territory. The detailed documentation associated with maimed soldiers provides some idea of the distances travelled by their less reputable comrades. Jeremiah Maye's journey from Basing House to his home in Essex, for example, involved a trip of almost one hundred miles. ${ }^{74}$ Entries in parish records during Charles I's campaigns in the 1620s show that unsupervised soldiers travelled anywhere up to 400 miles. ${ }^{75}$ Former vagrants had a distinct advantage in such circumstances, for, as Paul Slack has shown, the long distances and regular circuits they had travelled before the wars meant that many 'knew the roads of England like the backs of their hands. ${ }^{, 76}$

The patois developed within the military community was considered exceptionally rough and vulgar. Soldiers 'ought by their Profession to be as good at begging', opined a detractor after the Restoration, but 'they commonly act like themselves, bluntly, without consideration, and are usually denied without much ceremony. ${ }^{77}$ Episodes such as the Sussex alehouse brawl lent weight to this prejudice, but those who had been vagrants before their military service were probably more street-wise. Vagrants routinely exchanged information with others they met on the road, and were thus well aware which categories of traveller received the warmest welcome from parishes. It is therefore entirely possible that some individuals recorded in parish accounts as Irish refugees or victims of piracy may in actuality have been wandering soldiers. Traditional 'rogue' literature asserted that vagrants were practised impersonators, which made it all the more difficult for parish officials to ascertain which stories were genuine and which false. If it was indeed difficult for soldiers to conceal 
their occupation, it is particularly interesting that parish records of the 1640s should so often feature hybrid descriptions such as 'three distressed Souldiers which came out of Ireland', and 'two poore soldiers taken by the Turkes' ${ }^{78}$ Other variations on the theme include three English soldiers who passed through a Suffolk parish in 1643 claiming to have come from Germany, and the 'poore plundered souldier and his wife' who persuaded Swaffham officials to part with $6 \mathrm{~d} .{ }^{79}$

Experienced vagrants knew how to fake sickness or injury in order to achieve their aims. To this end, it is instructive to look closely at the specific nomenclature used by parish officials. Bona fide maimed soldiers were almost always recorded as such in parish records, not least because the description had a long-established legal status. The condition of others variously described as 'lame soldiers', 'sick soldiers', 'distressed soldiers', 'poor soldiers' , and combinations thereof is more ambiguous. Such terms appear to have been used judiciously - and quite possibly with the intention of introducing ambiguity. ${ }^{80}$ Soldiers' health was often poor - more than one died on the road through exhaustion and exposure but it was easy to feign illness. ${ }^{81}$ Parish officials had to bear in mind the very real possibility that wandering soldiers might be sick with plague or an equally lethal disease. Such considerations gave officials added incentive to take soldiers' stories at face value, and to usher them through to the next parish as quickly as possible.

The wording of parish records suggests that increasing numbers of individuals travelled without documentation. Even the accounts kept by the ultra-efficient constables of Upton, Nottinghamshire (who diligently recorded passes, commanding officers and other circumstances) suggest that unsupervised soldiers continued to slip through. ${ }^{82}$ During the course of the civil wars the gentry were divided by their conflicting loyalties to King, Parliament, religion and county, and by their reactions to the political revolution which followed. This influenced the administration of law and order even in counties not directly affected by fighting. Meanwhile, far more people were taking to the roads than had been the case in peacetime. Parish officials, facing an increasing workload, and confused by conflicts within the normal chain of command, do not seem to have demanded passes with the same alacrity as in previous decades. Maimed soldiers and war widows travelling to their home parishes could usually produce certificates, as the law required them to submit documentary evidence when applying for relief from the county Quarter Sessions. Firth claims that soldiers discharged by Parliament from 1647 onwards were routinely issued with passes, although few have survived ${ }^{83}$ Wandering soldiers, on the other hand, lacked passes but apparently had no need of an organised counterfeiting service, such as that discovered by Chester justices in $1601{ }^{84}$ Parliamentary ordinances demanding ever greater rigour in apprehending deserters therefore seem to have been somewhat divorced from the realities of parish administration. But then, wandering soldiers posed a different set of problems for those in high places.

Pym, Hampden, Strode, Holles and several other leading parliamentarians had played a prominent role in the protests against Charles I's imposition of martial law in the $1620 \mathrm{~s}-\mathrm{a}$ measure which had been taken in order to protect civilians from marauding soldiers. They could hardly maintain the moral high ground, nor expect to retain popular support, if they now indulged in the kind of arbitrary action they had so publicly opposed in the past. ${ }^{85}$ Parliament's initial response to mass desertion was therefore tentative. MPs' first inclination was to resort to bribery: in November 1642 every soldier who repaired to his colours and attended the earl of Essex's rendezvous set for later that month was promised an additional bounty over and above his normal pay. ${ }^{86}$ By the spring of 1643 , however, the Commons found it necessary to instruct the authorities in London, Westminster and the provinces to undertake a general search for deserters. ${ }^{87}$ Desertion from regional armies was left to local commanders to sort out. Clive Holmes has noted the series of warrants issued by the earl of Manchester, 'backed up by a variety of threats' which were sent to the constables of Croft, 
Lincolnshire between June 1644 and March 1645, 'ordering them to turn in any deserters who made their way back to the village. ${ }^{88}$

By the summer of 1644, with Pym and Hampden dead, and Strode dying, MPs grew sufficiently desperate to draw up the first of a series of ordinances instituting martial law in London, Westminster and other strategically sensitive areas. ${ }^{89}$ Presbyterian peers proved squeamish about such measures, even though they were intended to be of limited duration. In July 1644 the Commons felt it necessary to bully the Lords into extending the period of martial law, impressing upon their Lordships the ominous numbers of deserters gathering in and around London. ${ }^{90}$ Throughout the winter of 1644-45, the Lords repeatedly attempted to separate the issue of desertion from that of martial law. Meanwhile, those in the Commons urging a more energetic prosecution of the war against the King saw martial law as the only effective solution to desertion. ${ }^{91}$ The tide of desertion would only be stemmed if local civilian authorities could be coerced into stemming it.

The creation of the New Model Army intensified this wrangling. Its high desertion rate embarrassed the 'war party' (whose political credit depended largely upon the army's success), and alarmed the conservative Presbyterian 'peace' faction. It was therefore in their mutual interest to approve a new ordinance in April 1645, detailing draconian punishments for deserters. ${ }^{92}$ The mass exodus from the army after Naseby resulted in more extreme measures: an ordinance passed on 27 June 1645 authorised all county committees to impose martial law within their jurisdiction, and gave them the power to execute deserters. ${ }^{93}$ In January 1646 it was found necessary to extend the ordinance for a further nine months. County committees were now instructed to appoint provost-marshals. These were expected to deal with wandering soldiers, as Charles' provosts had done in the 1620s, and also to supervise the confinement of any disaffected individual. ${ }^{94}$ Despite these enhanced powers county committees did not execute swathes of deserters, not least because parish officials became ever more circumspect in their record-keeping. There are far fewer mentions of soldiers in the Cratfield churchwardens' accounts from the spring of 1645, for example, but more references to poor lame 'people', groups of 'travellers', and even '7 pore people that came from the hospital in Southerucke'. ${ }^{95}$ These seven were surely soldiers claiming to have been patients at St Thomas's hospital.

The issue of wandering soldiers took a further twist following the politicisation of the New Model and its estrangement from a Presbyterian-dominated Parliament. Deserters and demobilised soldiers were still camped in and around London in huge numbers, and there were rumours that Presbyterian MPs intended to form them into an army to counter the New Model. Sir Samuel Luke, Presbyterian governor of Newport Pagnell, was strongly suspected of attracting New Model deserters to his garrison for the same purpose. The New Model was alert to the danger, however, and warned MPs against proceeding further. ${ }^{96}$

Following Pride's Purge and the subsequent execution of the King in January 1649, the new military-backed Commonwealth was unpopular but secure, and able to expedite a gradual restoration of law and order in the provinces. Even so, the regime remained mindful of the political threat represented by wandering soldiers, and took precautions against an expected mass desertion of troops being sent to Ireland in July 1649. ${ }^{97}$ Large numbers of exsoldiers hanging around London continued to excite concern, as did the seepage of manpower from the New Model. In 1651 the Council of State warned county commissioners that 'many Souldiers in pay desert their colours, and retire into the country' ${ }^{98}$ However, when two deserters were caught in Sussex, the Council was sufficiently relaxed to order them simply to be delivered to the nearest army conductor, requesting that local officials impress upon the men 'that if they desert their colours again, they will be proceeded against according to law' ${ }^{99}$ In the event, the republic was to be undone not by deserters, but by Oliver Cromwell and the increasingly well-disciplined New Model. There is little mention of wandering 
soldiers in the legal records of the Cromwellian Protectorate - it would have been particularly embarrassing for a military dictatorship to admit there was a problem - but there are several references to localised concerns regarding vagrancy, felony and highway robbery. ${ }^{100}$ After the Restoration of 1660, many more military veterans took to the roads: the returning royalists ejected hundreds of maimed soldiers from London's military hospitals, thousands were discharged from Cromwell's 'Old Army', and many royalist prisoners-of-war are said to have returned from servitude in Barbados. These bodies of men, however, would pose a different set of problems for a very different regime. ${ }^{101}$

This study has sought to approach the complex problem of wandering soldiers from the varying perspectives of the men themselves, local civilian communities, and the parliamentary authorities in Westminster. With respect to the soldiers, it is wrong to assume that deserters, or even discharged veterans simply went home. Even those who did return to their parishes interacted with a series of civilian communities along the way, both positively and negatively. Many others had no permanent place of residence, and their military experience meant that they were substantially different, both in character and capability, from the more harmless vagrants of pre-war years. Nevertheless, David Underdown has argued that 'deserters and other masterless men who took to a life of crime were not engaging in a form of social protest, but simply trying to survive. ${ }^{102}$ Joining a criminal gang was often an act of self-defence. Wandering soldiers feared civilians as much as civilians feared them.

Even in times of peace, petty constables and churchwardens had frequently found themselves squeezed between the prerequisites of their local community and the political imperatives of higher authority. The particular circumstances of the civil wars necessitated a renegotiation of authority, between parish officials and county rulers, and between county rulers and Westminster. The issues surrounding wandering soldiers laid bare many of the fundamental tensions between the lawmakers in Parliament and those expected to enforce their will in the localities. Far from being able to harness the power of localism to solve the problem of the wandering soldier, parliamentarian leaders found local communities unable or unwilling to cooperate. As a result, what began as an embarrassment became a serious threat to the war effort, to parliamentarian unity, and to Parliament's moral authority. The unsettling presence of wandering soldiers in the localities fed into royalist rhetoric regarding incipient societal chaos at the same time as it threatened to undermine Parliament's self-image as the guardian of the people and the Common Law. Inaction would give the impression of incompetence, and unfitness to rule, whereas positive measures courted accusations of tyranny. Charles I's opponents therefore found themselves facing many of the same problems which had bedevilled the King in the 1620s. As they were forced to adopt ever more arbitrary policies, MPs knew that they risked similar opprobrium to that which they had heaped upon Charles. Wandering soldiers did not represent a mere political problem for the parliamentarian leadership as much as an existential crisis.

Notes

${ }^{1}$ Quoted in T. Barnes, 'Deputies not principals, lieutenants not captains: the institutional failure of lieutenancy in the 1620s', in M. Fissel (ed.), War and Government in Britain 15981650 (Manchester: Manchester University Press, 1991), p. 59.

${ }^{2}$ I. Gentles, The English Revolution and the Wars in the Three Kingdoms 1638-1652

(Harlow: Pearson Longman, 2007), p. 436.

${ }^{3}$ C. H. Firth, Cromwell's Army: A History of the English Soldier during the Civil Wars, the Commonwealth and the Protectorate (London: Greenhill, 1992, facsimile of 1902 ed.), pp. 
268-75; C. Holmes, The Eastern Association in the English Civil War (Cambridge: Cambridge University Press, 1974), pp. 39, 168, 169; A. Fletcher, A County Community in Peace and War: Sussex 1600-1660 (London: Longman, 1975), pp. 341-2; M. Kishlansky, The Rise of the New Model Army (Cambridge: Cambridge University Press), pp. 241, 244-5, 247, 249; C. Carlton, Going to the Wars: The Experience of the British Civil Wars (London: Routledge, 1992), pp. 196, 225, 235.

${ }^{4}$ R. Bennett, 'War and disorder: policing the soldiery in Civil War Yorkshire', in Fissel (ed.), War and Government in Britain, pp. 248-73.

${ }^{5}$ I. Gentles, The New Model Army in England, Ireland and Scotland, 1645-1653 (Oxford: Blackwell, 1992), pp. 33, 37-8, 389, 392, 402; B. Donagan, War in England 1642-1649 (Oxford: Oxford University Press, 2008), pp. 263-75.

${ }^{6}$ P. Thomas, 'Vagabond soldiers and deserters at Elizabethan Northampton', Northamptonshire Past \& Present, 9:2 (1995), 101-10; P. Thomas, 'The Elizabethan Privy Council and soldiers at York in a time of war: deserters, vagrants and crippled exservicemen', York Historian, 13 (1996), 15-24; G. Phillips, 'To cry “Home! Home!”: mutiny, morale and indiscipline in Tudor armies', Journal of Military History, 65:2 (2001), 313-32; L. Salamon, 'Vagabond veterans: the roguish company of Martin Guerre and Henry V', in C. Dionne and S. Mentz (eds), Rogues and Early Modern English Culture (Ann Arbor: University of Michigan Press, 2004), pp. 261-93; J. Childs, 'War, crime waves and the English army in the late seventeenth century', War \& Society, 15:2 (1997), 1-17; N. Garnham, 'Desertion and deserters in eighteenth-century Ireland', Eighteenth-Century Ireland, 20 (2005), 91-103; T. Agostini, “"Deserted his Majesty's service": military runaways, the British-American press, and the problem of desertion during the Seven Years' War', Journal of Social History, 40:4 (2007), 957-98.

7 J. Sharpe, 'History from below', in P. Burke (ed.), New Perspectives on Historical Writing ( $2^{\text {nd }}$ ed., London: Polity Press, 2001), p. 31; G. Rudé, The Crowd in History (London: John Wiley, 1964, revised ed. 1981); J. Walter, Crowds and Popular Politics in Early Modern England (Manchester: Manchester University Press, 2006); A. Beier, 'Vagrants and the social order in Elizabethan England', Past \& Present, 64 (1974), 3-29, esp. 3, 26; A. Beier,

Masterless Men: The Vagrancy Problem in England, 1560-1640 (London: Methuen, 1985); S. Hindle, 'Power, poor relief, and social relations in Holland Fen, 1500-1800', Historical Journal, 41:1 (1998), 67-96; S. Hindle, On the Parish? The Micro-Politics of Poor Relief in Rural England, c.1550-1750 (Oxford: Oxford University Press, 2004).

${ }^{8}$ P. Burke, 'History of events and the revival of narrative', in Burke (ed.), New Perspectives on Historical Writing, p. 291; J. Walter, Understanding Popular Violence in the English Revolution: the Colchester Plunderers (Cambridge: Colchester University Press, 1999), pp. 7-8.

${ }^{9}$ I. Gentles, 'Why men fought in the British Civil Wars, 1639-1652', The History Teacher, 26:4 (1993), 408.

${ }^{10}$ Essex Record Office (hereafter ERO), Q/SBa2/78; BL, Egerton MS 2,647, fo. 166.

${ }^{11}$ Notes \& Queries, fourth series, 11 (1873), p. 430.

${ }^{12}$ BL, Thomason E128(30), A Most Worthy Speech Spoken by the Right Honourable Robert Earl of Warwick (London, 1642), pp. 1-2; BL, Thomason E127(9), H. Farre, A Speech Spoken unto his Excellencie the Earle of Warwicke by Captain Farres in the Behalf of the Whole County of Essex (London, 1642), p. 3; C. Holmes, 'The Eastern Association' (PhD thesis, University of Cambridge, 1969), p. 110; A. Kingston, East Anglia and the Great Civil War (Godmanchester: Trotman, 2005), p. 133; BL, Egerton MS 2,647, fo. 241.

${ }^{13}$ TNA, SP 28/129, fo. 23.

${ }^{14}$ TNA, SP 21/16, fo. 243. 
${ }^{15} L J$, viii, pp. $267-8$.

${ }^{16}$ Gentles, New Model Army, p. 34.

17 TNA, SP 16/501, fo. 152 .

${ }^{18}$ LJ, viii, pp. 267-8.

${ }^{19}$ M. Fissel, English Warfare 1511-1642 (London: Routledge, 2001), p. 108.

${ }^{20}$ Agostini, 'Deserted his Majesty's service', 963; Garnham, 'Deserters and desertion', 1012.

${ }^{21}$ Fissel, English Warfare, p. 108.

${ }^{22}$ BL, Egerton MS 2,647, fo. 199.

${ }^{23}$ Wing A3258, Another Extract of More Letters Sent out of Ireland, informing the Condition of the Kingdome as it Now Stands (London, 1643), p. 5.

24 TNA, SP 21/17, fo. 173.

${ }^{25}$ STC ( $2^{\text {nd }}$ ed.) 17393 , G. Markham, The Second Part of the Souldiers Grammar (London, 1643), p. 156.

${ }^{26}$ Quoted in Kingston, East Anglia, p. 147.

${ }^{27}$ BL, Thomason E75(34), Lawes and Ordinances of Warre, by his Excellency the Earl of Essex (London, 1643), sig. C; Wing L696A, Laws and Ordinances of Warre, by Colonell Michael Iones (Dublin, 1647), sig. B.

${ }^{28}$ BL, Thomason E126(13), E. Kightley, A Full and True Relation of the Great Battle Fought between the King's Army, and his Excellency, the Earl of Essex (London, 1642), pp. 4-5.

${ }^{29}$ East Sussex Record Office (ESRO), Danny MS 85, quoted in Donagan, War in England, p. 302.

${ }^{30}$ BL, Thomason E126(13), Kightley, Full and True Relation, pp. 6-7.

${ }^{31}$ T. Venn, Military \& Maritine [sic] Discipline in Three Books (London, 1672), I, pp. 5, 188-9, Markham, Second Part of the Souldiers Grammar, p. 123; J. Turner, Pallas Armata (London, 1683), p. 223.

${ }^{32}$ Denbighshire Record Office, GB 0209 BD/B, cited in D. Evans, Montgomery 1644: The Story of the Castle and Civil War Battle (Llanidloes: March Publications, n.d.), p. 31;

Holmes, Eastern Association, p. 168, n. 46.

33 BL, Thomason E345(2), Articles for the Delivering Up of Lichfield-Close (London, 1646), p. 7.

${ }^{34}$ Gentles, The New Model Army, p. 37; Gentles, The English Revolution, p. 103.

${ }^{35} \mathrm{BL}$, Thomason E288(46), The True Informer, 21 June (London, 1645), pp. 68, [70].

${ }^{36}$ BL, Thomason E292(5), The Scotish Dove, no. 89, 27 June - 4 July (London, 1645), p.

700. According to one old royalist, the prisoners were held in London for four months: HMC, Manuscripts of Rye and Hereford Corporations, Etc. Thirteenth Report, Appendix, Part IV (London: HMSO, 1892), p. 346.

${ }^{37}$ G. Foard, Naseby: the Decisive Campaign (Whitstable: Prior Publications, 1995), pp. 3067.

${ }^{38}$ Holmes, Eastern Association, pp. 38-9.

${ }^{39}$ BL, Stowe MS 842, fo. 6; I. Slocombe (ed.), Wiltshire Quarter Sessions Order Book, 1642-1654 (Chippenham: Wiltshire Record Society, 67, 2014), p. 302; Suffolk Record

Office (Ipswich), FC62/A6/211.

${ }^{40}$ Fletcher, Sussex, p. 341.

${ }^{41}$ Lancashire Archives, QSB/1/295/36.

${ }^{42}$ L. A. Botelho (ed.), Churchwardens' Accounts of Cratfield (Woodbridge: Suffolk Records Society, 42, 1999), p. 20.

${ }^{43}$ BL, Thomason E1243(2), R. Cotton, Cottoni Posthuma, ed. J. Howell (London, 1651), p. 312. 
${ }^{44}$ Clarke MS 41, fo. 122, quoted in Kishlansky, Rise of the New Model Army, p. 214.

${ }^{45}$ T. Otway, Titus and Berenice (London, 1677), epilogue.

${ }^{46}$ STC 24760.7, P. Vincent, The Lamentations of Germany (London, 1638); BL, Thomason 669 f.6(12) The English-Irish Soldier (London, 1642); BL, Thomason E1448(1) and Wing C6370, J. Cotgrave, Wits Interpreter (London, 1655), p. 143.

${ }^{47} \mathrm{BL}$, Thomason E69(15), H. Foster, A True and Exact Relation of the Marchings of the Two Regiments of the Trained Bands of the City of London (London, 1643), sig. B3.

${ }^{48}$ R. Holmes, Acts of War (London: Cassell, 2003), pp. 376-80.

${ }^{49}$ Kent History and Library Centre, Q/SO E1, fo. 64; Stafford Record Office (hereafter SRO), Q/SR E1652, fo. 20; C. Mayo (ed.), The Minute Books of the Dorset Standing Committee $23^{\text {rd }}$ Sept., 1646 to $8^{\text {th }}$ May, 1650 (Exeter: William Pollard, 1902), p. 80.

50 TNA, SP 12/261, fo. 70, quoted in J. Cockburn, 'Patterns of violence in English society: homicide in Kent 1560-1985', Past and Present, 130 (1991), 85; ERO, Morant MS D/Y 2/5, fo. $95,2 / 8$, fo. 259 .

${ }^{51}$ Bennett, 'War and disorder', pp. 250, 261, 262. See also SRO, Q/SR M.1647, fo. 11. For those sceptical of the extent of the violence, see Cockburn, 'Patterns of violence', 85; Barnes, 'Deputies not principals, lieutenants not captains', 75.

${ }^{52}$ STC ( $2^{\text {nd }}$ edn) 12787.5, T. Harman, Caveat for Common Cursitors (London, 1567). See the survey of vagrant historiography in P. Clark, 'Migration in England during the late seventeenth and early eighteen centuries', in P. Clark and D. Souden (eds), Migration and Society in Early Modern England (London: Hutchinson, 1987), pp. 213-15. One scholar who has considered aspects of the civil-war period is L. Woodbridge, 'The neglected soldier as vagrant, revenger, tyrant slayer in early modern England', in A. Beier and P. Ocobock (eds), Cast Out: Vagrancy and Homelessness in Global and Historical Perspective (Athens $\mathrm{OH}$ : Ohio University Press, 2008), esp. pp. 71-82.

${ }^{53}$ Fletcher, Sussex, p. 341.

${ }^{54}$ STC (2 ${ }^{\text {nd }}$ ed.) 994.5, J. Awdelay The Fraternity of Vagabonds (London, 1603 edn.), sig. A2.

${ }^{55}$ BL, Thomason 669 f.10(2), A True Report of the Great Costs and Charges of the Foure Hospitals (London, 1644). London's military hospitals were funded separately, and do not feature in the report.

${ }^{56}$ Parliamentary Archives, HL/PO/JO/10/1/235; LJ, ix, p. 265.

${ }^{57}$ Wing H3119, J. Howell, Therologia, The Parly of Beasts (1660), pp. 114, 117.

${ }^{58}$ STC $\left(2^{\text {nd }}\right.$ ed.) 18098, T. More, The Common-wealth of Utopia (London, 1639 edn.), pp. 29-30.

${ }^{59}$ BL, Thomason E266(37), Perfect Occurrences of Parliament, 2 January (London, 1647), sig. [A4].

${ }^{60}$ Mayo (ed.), Minute Books of the Dorset Standing Committee, p. 169.

${ }^{61}$ Slocombe (ed.), Wiltshire Quarter Sessions Order Book, pp. 55-6.

${ }^{62}$ Fletcher, Sussex, p. 341.

${ }^{63}$ HMC, Manuscripts of Rye and Hereford Corporations, p. 216.

${ }^{64}$ TNA, SP 16/507, fo. 16.

${ }^{65}$ TNA, SP 21/17, fo. 165.

${ }^{66}$ Ibid.

${ }^{67}$ ERO, D/P 256/5, fo. 51.

${ }^{68}$ ESRO, Sessions Rolls 70/76, fo. 77, 80/64, fo. 65, cited in Fletcher, Sussex, p. 341.

${ }^{69}$ ERO, Q/SO1, fo. 203v; SRO, Q/SR M.1647, fo. 11.

${ }^{70}$ Agostini, 'Deserted his Majesty's service', 959, 971. 
${ }^{71}$ BL, Thomason 669 f.25(58), The Lamentation of a Bad Market, or the Disbanded Soldier (London, 1660); Wing S2698, E. Settle, Love and Revenge (London, 1672), pp. 1-2; Wing D2789, T. D'Urfey, Trick for Trick (London, 1678), prologue. Red coats are noted in parish records as early as 1625: J. Stocks (ed.), Market Harborough Parish Records (London: Oxford University Press, 1926), p. 92.

72 Wing H2969, E. Howard, The Man of Newmarket (1678), p. 28.

${ }^{73}$ Donagan, War in England, p. 271.

${ }^{74} \mathrm{ERO}, \mathrm{Q} / \mathrm{SBa} 2 / 78$.

${ }^{75}$ Stocks (ed.), Market Harborough Parish Records, pp. 90, 96, 97.

${ }^{76}$ Slack, 'Vagrants and vagrancy in England, 1598-1664', in Clark and Souden (eds), Migration and Society in Early Modern England, p. 58.

${ }^{77}$ Wing B3742, F. Boothby, Marcelia, or, The Treacherous Friend (1670), sig. D2.

${ }^{78}$ A. Craven (ed.), The Churchwardens' Account of St Mary's Devizes 1633-1689

(Chippenham: Wiltshire Record Society, 2016), pp. 57, 62; Botelho (ed.), Churchwardens' Accounts of Cratfield, pp. 34, 47, 55.

${ }^{79}$ Ibid., p. 55; Norfolk Record Office (hereafter NRO), Swaffham churchwardens' accounts 1627-52, PD52/72, fo. 13 - a reference I owe to the kindness of Patricia Appleby.

${ }^{80}$ Numerous instances of each category appear in Craven (ed.), Churchwardens' Account of St Mary's Devizes; NRO, PD52/72; ERO, D/P 75/5/1; ERO, D/P 265/5; Botelho (ed.), Churchwardens' Accounts of Cratfield; Market Harborough Parish Records; M. Bennett (ed.), A Nottinghamshire Village in War and Peace: The Accounts of the Constables of Upton, 1640-1666 (Nottingham: Thoroton Society Record Series, 39, 1995), pp. 20-21, 23.

${ }^{81}$ ESRO, PAR498/1/1/3.

${ }^{82}$ Bennett (ed.), Nottinghamshire Village, pp. 8, 9, 10, 16, 18.

${ }^{83}$ Firth, Cromwell's Army, pp. 269-70.

${ }^{84}$ Cheshire Archives, QSF/49, fos. 27, 86, 91

${ }^{85}$ Donagan, War in England, pp. 171-3. See also J. M. Collins, Martial Law and English Laws, c.1500-c.1700 (Cambridge: Cambridge University Press, 2016), chapter 5.

${ }^{86} \mathrm{CJ}$, ii, pp. 841-2.

${ }^{87}$ CJ, iii, pp. 49, 107.

${ }^{88}$ Holmes, Eastern Association, p. 168, note 46.

${ }^{89}$ LJ, vi, pp. 673-4, 681; vii, pp. 88, 333-4, 402, 418-19; viii, pp. 23, 29, 30, 106, 200.

${ }^{90} C J$, iii, p. 568.

${ }^{91} C J$, iii, p. 693.

${ }^{92} L J$, vii, pp. 334-5.

${ }^{93}$ LJ, vii, p. 461; BL, Thomason E290(3), An Ordinance of the Lords and Commons (London, 1645).

${ }^{94}$ LJ, viii, pp. 102-3; BL, Thomason E316(12), An Ordinance of the Lords and Commons (London, 1646); Mayo (ed.), Minute Books of the Dorset Standing Committee, p. 169;

Parliamentary Archives: HL/PO/JO/10/1/199.

${ }^{95}$ Bothelho (ed.), Churchwardens' Accounts of Cratfield, pp. 63, 64, 70, 71, 72, 77, 79, 92 , 95; Carven (ed.), Churchwardens' Account of St Mary's Devizes, p. 44.

${ }^{96}$ Kishlansky, Rise of the New Model Army, pp. 241, 244-5, 249; H. Tibbutt (ed.), The Letter Books of Sir Samuel Luke, 1644-45 (London: HMSO, 1963), pp. 561, 564.

97 TNA, SP 25/62, fo. 494.

${ }^{98}$ TNA, SP 25/96, fo. 35; C. H. Firth and R. S. Rait (eds), Acts and Ordinances of the Interregnum, 1642-1660, 3 vols (London: HMSO, 1911), ii, p. 349.

${ }^{99}$ TNA, SP 25/65, fo. 265. 
${ }^{100}$ Firth and Rait (eds), Acts and Ordinances, ii, pp. 1098, 1262; CJ, vii, pp. 530, 552, 570-1, 577.

${ }^{101}$ D. J. Appleby, 'Veteran politics in Restoration England 1660-1670', The Seventeenth Century, 28:3 (2013), 326-8, 333; B. Garside, Parish Affairs in Hampton Town during the Seventeenth Century (Richmond: Dimbleby, 1954), p. 48.

102 D. Underdown, Revel, Riot and Rebellion: Popular Politics and Culture in England, 1603-1660 (Oxford: Oxford University Press, 1985), p. 159. 